\title{
Pulmonary embolism complicating the course of COVID-19 - an underestimated condition?
}

\section{Zatorowość płucna w przebiegu COVID-19 - niedoszacowane zjawisko?}

\author{
Paweł Pabjan 1,2, Piotr Błoniarczyk², Piotr M. Stępieńn,2, Anna Garbat², Maciej Włosek³, \\ Dorota Zarębska-Michaluk ${ }^{1,2}$ \\ ${ }^{1}$ Jan Kochanowski University, Kielce, Poland \\ ${ }^{2}$ Department of Infectious Disease, Provincial Hospital, Kielce, Poland \\ Head of the Department: Paweł Pabjan \\ ${ }^{3}$ Radiology Department, Provincial Hospital, Kielce \\ Head of the Department: Łukasz Wypchło
}

Medical Studies/Studia Medyczne 2020; 36 (3): 206-210

DOI: https://doi.org/10.5114/ms.2020.99542

Key words: computed tomography angiography, pulmonary embolism, COVID-19, SARS-CoV-2.

Słowa kluczowe: angiografia tomografii komputerowej, zatorowość płucna, COVID-19, SARS-CoV-2.

\begin{abstract}
SARS-CoV-2 (severe acute respiratory syndrome coronavirus 2) was discovered in Wuhan, China at the end of 2019 and is believed to be the cause of COVID-19 (coronavirus disease 2019). There is some evidence that SARS-CoV-2 infection can be complicated by pulmonary embolism. However, the pathomechanism of this relation is not fully understood, and data are still limited. The real incidence of this condition is not known, and available papers in the literature on this issue comprise case presentations and one report from a prospective multicentre study published very recently. Pulmonary angiography computed tomography seems to play a crucial role, allowing early and proper diagnosis of this condition. The timely recognition of pulmonary embolism is essential for the implementation of anticoagulant treatment.
\end{abstract}

\section{Streszczenie}

Wirus SARS-CoV-2 (severe acute respiratory syndrome coronavirus 2) odkryty pod koniec 2019 r. w chińskim mieście Wuhan jest czynnikiem etiologicznym COVID-19 (coronavirus disease 2019). Zgodnie z doniesieniami piśmiennictwa przebieg kliniczny zakażenia SARS-CoV-2 może być powikłany zatorowością płucną. Patomechanizm występowania tego powikłania w przebiegu COVID-19 nie jest do końca poznany, a dane kliniczne dotyczace jego ryzyka i częstości występowania sa bardzo skąpe. Dostępne prace na ten temat ograniczają się do opisów przypadków i jednego nowo opublikowanego raportu z wieloośrodkowego badania prospektywnego. Decydujacca rolę w rozpoznaniu zatorowości płucnej odgrywa tomografia komputerowa naczyń krwionośnych klatki piersiowej. Wczesne rozpoznanie zatorowości płucnej jest kluczowe dla wdrożenia terapii przeciwkrzepliwej.

\section{Introduction}

Since December 2019 the novel coronavirus SARSCoV-2 (severe acute respiratory syndrome coronavirus 2) has appeared in most countries all over the world [1]. In the face of the rapid increase in the number of COVID-19 (coronavirus disease 2019) cases, on 11 March 2020 World Health Organisation (WHO) announced the outbreak of a pandemic. New SARSCoV-2 infections are still being diagnosed all over the world, and some affected patients seem to develope additional complications in the course of the disease
$[2,3]$. Among them, acute pulmonary embolism (PE) has been described [4]. However, the pathomechanism of the relation between COVID-19 and coagulopathy leading to PE is not fully understood, and data are still limited. The true incidence of this condition is not known, and available papers in the literature on this issue comprise case presentations and one report from a prospective multicentre study published very recently [5]. Herein, we present a patient with COVID-19 complicated by mild pulmonary embolism diagnosed based on computed tomography (CT) pul- 
monary angiography, and a review of available publications regarding this complication of the disease.

\section{Pulmonary embolism in the course of COVID-19}

A 46-year-old man with no comorbidities was admitted to the department with a five-day history of malaise, fever, and dry cough. A week previously he had returned from a European country in which the epidemic of COVID-19 had already been announced. Although he denied having any direct contact with a person diagnosed with SARS-CoV-2 infection he was in quarantine according to current official recommendations. On admission, vital signs were as follows: body temperature $38.5^{\circ} \mathrm{C}$, blood pressure $120 / 80 \mathrm{~mm} \mathrm{Hg}$, heart rate $100 \mathrm{bpm}$, respiratory rate 14 per minute, weight $94 \mathrm{~kg}$, height $190 \mathrm{~cm}$, and body mass index 26.04. Singular crackles were heard over the left lung on auscultation. Baseline oxygen saturation was $98 \%$, and a chest X-ray revealed decreased translucency of the lower part of the left lung corresponding to interstitial changes (Figure $1 \mathrm{~A}$ ). Realtime reverse transcriptase-polymerase chain reaction (rRT-PCR) from the nasopharyngeal swab specimen was positive for SARS-CoV-2 confirming a diagnosis of COVID-19. The patient was treated according to recommendations [6], and pharmacological treatment with chloroquine, lopinavir/ritonavir, and empirical antibiotic therapy was applied. After 3 days of hospitalisation, routine blood tests showed a significant drop in platelet counts to $46 \times 10^{9} / 1$ with no symptoms of haemorrhagic diathesis. Initially, thrombocytopaenia was considered as a side effect of chloroquine, and so the drug was discontinued. However, a control blood test revealed a further drop in platelet counts to $26 \times 10^{9} / 1$. Due to the hypothesis of the immunological nature of this condition complicating the course of COVID-19, methylprednisolone was administered in an initial dose of $80 \mathrm{mg}$ intravenously with a sub- sequent increase of platelet count to $169 \times 10^{9} / 1$ during $24 \mathrm{~h}$. Due to a quick response, the dose of methylprednisolone was reduced in stages to $10 \mathrm{mg}$ and was finally completed after 12 days. A gradual improvement of the patient's condition was observed with a resolution of clinical symptoms, normalisation of $\mathrm{C}$-reactive protein (CRP), and regression of radiologic changes assessed by X-ray (Figure $1 \mathrm{~B}$ ). The clinical condition of the patient was good, no lab abnormalities were observed, and pharmacological treatment was completed according to plan, hence he was scheduled to be discharged. However, on the following day, the patient complained about right-sided abdomen pain. Physical examination revealed a soft abdomen without peritoneal signs, and tenderness in the right hypochondrium. Laboratory tests showed leucocytosis with a high rate of neutrophils, an increase of CRP level, and a significant elevation of D-dimer level to $2400 \mu \mathrm{g} / \mathrm{l}$. Blood cultures were negative and the procalcitonin level was within the normal range. A prophylactic dose of low-molecular-weight heparin (LMWH) was started, and meropenem with metronidazole intravenously was introduced due to suspicion of cholecystitis. However, the ultrasonography and computed tomography (CT) scan of the abdomen did not confirm this diagnosis. Although the patient showed no respiratory discomfort, no abnormal sounds on auscultation, and control X-ray was normal, a nonenhanced chest CT was performed revealing grand glass opacities in both lungs. Due to the presence of those typical changes in the CT scan despite a normal appearing X-ray, and since the cholecystitis was excluded, we considered a further diagnostic procedure searching for a reason for the elevated leucocyte count, CRP, and D-dimer level. Pulmonary angiography CT was performed, which showed filling defects in the sub-segmental and segmental arterial branches of both lungs consistent with acute PE (Figures $2 \mathrm{~A}-\mathrm{E}$ ). A full dose of nadroparin was implemented. The patient showed clinical improvement, and despite re-
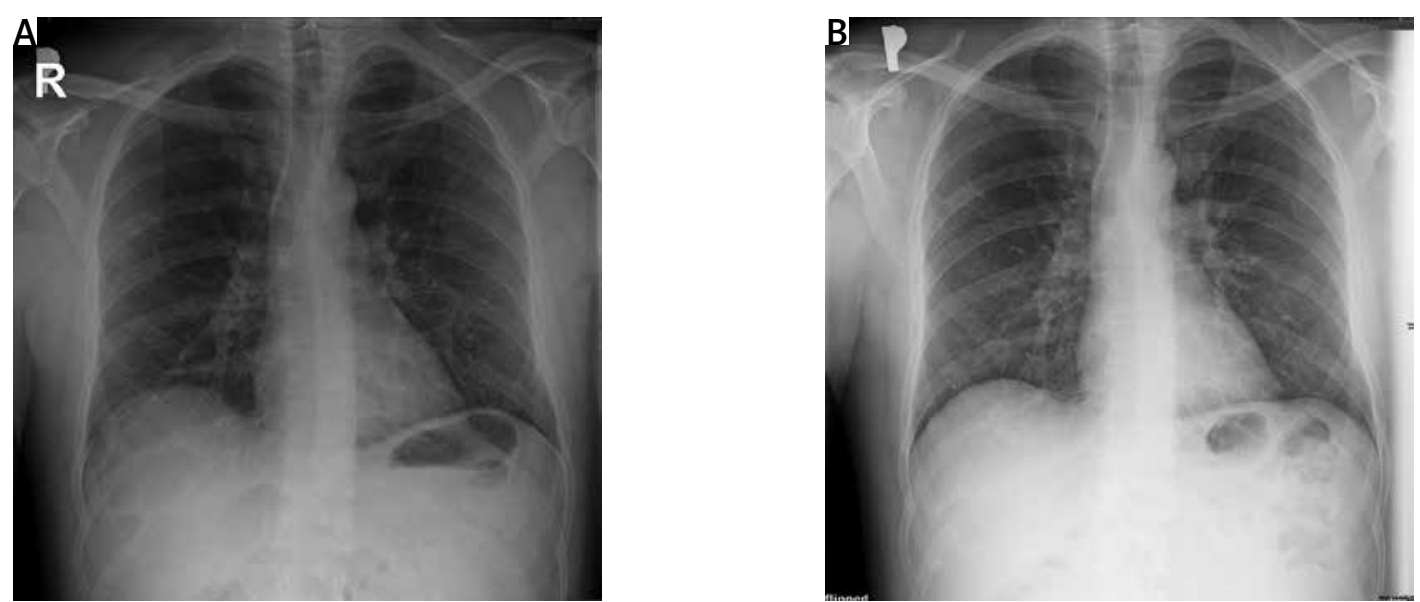

Figure 1. A - X-ray at baseline: decreased translucency of the lower part of the left lung, B - control X-ray - normal 

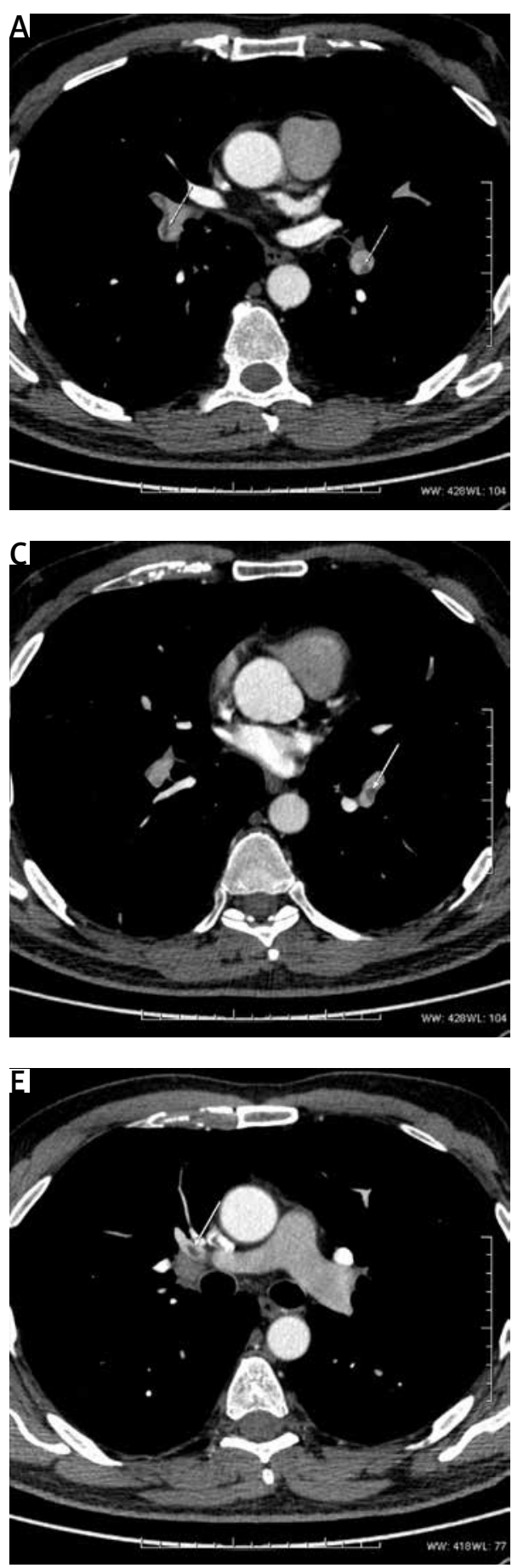

peatedly inconclusive results of control nasopharyngeal swabs for SARS-CoV-2, he was discharged after 10 days of full anticoagulation, with prescription of rivaroxaban. Home isolation was completed within next 7 days due to two subsequent negative molecular tests for SARS-CoV-2. The control chest CT scan performed after 8 weeks revealed significant regression of lung lesions and no signs of pulmonary fibrosis; laboratory tests showed no coagulation abnormalities.
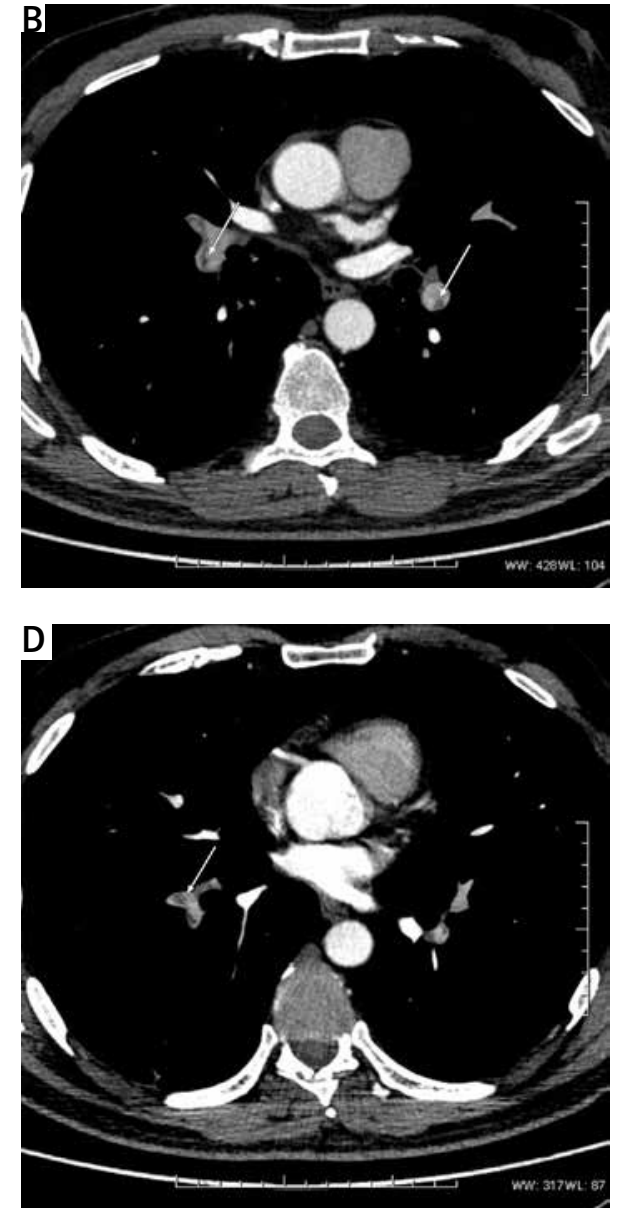

Figure 2. A - Computed tomography (CT) angiography scan - filling defect in the division of the right pulmonary artery into lobar branches (arrow on the left side of the image) and in the left inferior lobe pulmonary artery (arrow on the right side of the image). B - CT angiography scan - filling defect in the left inferior lobe pulmonary artery (arrow). C - CT angiography scan - filling defect in the division of the left lobe pulmonary artery into segmental arteries to left 9/10 segments (arrow), D - CT angiography scan - filling defect in the division of the right lobe pulmonary artery into segmental arteries to right 9/10 segments (arrow). E - CT angiography scan - filling defect in the right superior lobe pulmonary artery (arrow)

\section{Discussion}

Most patients affected by SARS-CoV-2 infection are usually asymptomatic or present mild symptoms including fever, muscle pain, shortness of breath, cough, dysgeusia, parosmia, and fatigue. However, some of them develop a more serious clinical presentation, which is viral pneumonia with a risk of various complications. The imaging technique of choice when 
COVID-19-related pneumonia is suspected is nonenhanced chest CT identifying typical parenchymal changes [7]. Some case reports have been published regarding pulmonary embolism as a complication of pneumonia in the course of COVID-19 $[8,9]$. The exact pathomechanism of coagulopathy leading to PE in SARS-CoV-2 infection is not fully understood but seems to be multifactorial. The inflammatory injury of the blood vessel's endothelium by viral direct and cytokine-mediated damage plays a crucial pathogenetic role [10]. Almost all available papers report this coagulopathy in patients with the severe form of SARS-CoV-2 pneumonia and coexisting risk factors for PE [5, 11-13]. Recently published results from a prospective French study conducted among 150 critically ill patients in four intensive care units confirmed the high incidence of PE (16.7\%) in patients with acute respiratory distress syndrome (ARDS) secondary to COVID-19 despite anticoagulation [5]. However, there have been isolated publications describing PE even in patients with a mild course of the disease and no risk factors for coagulopathy [12]. We present a case of PE complicating the COVID-19 in a patient with a mild clinical course of viral pneumonia, no predisposing factors, and no comorbidities. The patient did not complain of any typical symptoms of acute pulmonary embolism, such as dyspnoea, chest pain, cough, or haemoptysis, and oxygen saturation was over $95 \%$ all the time. According to Wells rules, Geneva score, YEARS algorithm, and Pulmonary Embolism Rule-out Criteria the diagnosis of PE was unlikely [14]. The only premise for pulmonary angiography CT was an elevated D-dimer level, which allows the assumption that some cases of concurrent PE and COVID-19-related pneumonia remain unrecognised in patients with mild or uncharacteristic symptoms of the disease. The only means of detection of pulmonary emboli is by broader diagnostic measures, and the imaging technique that should be applied for this purpose is chest angiography CT $[15,16]$. Our findings support the recommendation to use a prophylactic dose of LMWH in patients with confirmed COVID-19 even in the stable course of the disease with absence of major risk factors for coagulopathy [17]. If pulmonary embolism is diagnosed, the full-dose LMWH with subsequently extended thromboprophylaxis post-discharge should be administered according to guidelines [18].

\section{Conclusions}

In some cases, patients diagnosed with COVID-19 may develop serious complications. According to reports, one of them is pulmonary embolism. Pulmonary angiography CT seems to play a crucial role, allowing early and proper diagnosing this condition. The timely recognition of pulmonary embolism is essential for the implementation of anticoagulant treatment.

\section{Acknowledgments}

Project financed under the program of the Minister of Science and Higher Education called "Regional Initiative of Excellence" in the years 2019-2022, project no. 024/RID/2018/19, amount of financing $11999000,00 \mathrm{zl}$.

\section{Conflict of interest}

The authors declare no conflict of interest.

\section{References}

1. Valencia DN. Brief review on COVID-19: the 2020 pandemic caused by SARS-CoV-2. Cureus 2020; 12: e7386.

2. Long B, Brady WJ, Koyfman A, Gottlieb M. Cardiovascular complications in COVID-19. Am J Emerg Med 2020; 38: 1504-1507.

3. Terpos E, Ntanasis-Stathopoulos I, Elalamy I, Kastritis E, Sergentanis TN, Politou M, Psaltopoulou T, Gerotziafas G, Dimopoulos MA. Hematological findings and complications of COVID-19. Am J Hematol 2020; 95: 834-847.

4. Jasinowodolinski D, Filisbino MM, Baldi BG. COVID-19 pneumonia: a risk factor for pulmonary thromboembolism? J Bras Pneumol 2020; 46: e20200168.

5. Helms J, Tacquard C, Severac F, et al. High risk of thrombosis in patients with severe SARS-CoV-2 infection: a multicenter prospective cohort study. Intensive Care Med 2020; 46: 1089-1098.

6. Flisiak R, Horban A, Jaroszewicz J, Kozielewicz D, Pawłowska M, Parczewski M, Piekarska A, Simon K, Tomasiewicz K, Zarębska-Michaluk D. Management of SARSCoV-2 infection: recommendations of the Polish Association of Epidemiologists and Infectiologists as of March 31, 2020. Pol Arch Intern Med 2020; 130: 352-357.

7. Rogalska-Płońska M, Kuźmicz A, Łapiński TW, Flisiak R. Abnormalities on chest computed tomography in patients with coronavirus disease 2019. Pol Arch Intern Med 2020; 130: 541-543.

8. Chen J, Wang X, Zhang S. Findings of acute pulmonary embolism in COVID-19 patients. Lancet Infect Dis 3/1/2020 doi: 10.2139/ssrn.3548771.

9. Giannis D, Ziogas IA, Gianni P. Coagulation disorders in coronavirus infected patients: COVID-19, SARS-CoV-1, MERS-CoV and lessons from the past. J Clin Virol 2020; 127: 104362.

10. Tamburello A, Bruno G, Marando M. COVID-10 and pulmonary embolism: not a coincidence. EJCRIM 2020; 7: doi: 10.12890/2020_001692.

11. KlokFA, Kruip MJHA, van derMeer NJM, Arbous MS, Gommers D, Kant KM, Kaptein FHJ, van Paassen J, Stals MAM, Huisman MV, Endeman H. Confirmation of the high cumulative incidence of thrombotic complications in critically ill ICU patients with COVID-19: an updated analysis. Thromb Res 2020; 191: 148-150.

12. Bavaro DF, Poliseno M, Scardapane A, Belati A, De Gennaro N, Stabile Ianora AA, Angarano G, Saracino A. Occurrence of acute pulmonary embolism in COVID-19 a case series. Int J Infect Dis 2020; 98: 225-226.

13. Moreira BL, Santana PRP, Zanetti G, Marchiori E. COVID-19 and acute pulmonary embolism: what should be considered to indicate a computed tomography pulmonary angiography scan? Rev Soc Bras Med Trop 2020; 53: e20200267. 
14. Stuppner S, Ruiu A. Correlation of acute pulmonal embolism with D-dimer levels and the diameter of the pulmonary trunk in thoracic multislice computed tomography. A single-centre retrospective analysis of 100 patients. Pol J Radiol 2019; 84: e347-e352.

15. Rotzinger DC, Beigelman-Aubry C, von Garnier C, Qanadli SD. Pulmonary embolism in patients with COVID-19: time to change the paradigm of computed tomography. Thromb Res 2020; 190: 58-69.

16. Cieszanowski A, Czekajska E, Giżycka B, Gruszczyńska K, Podgórska J, Oronowicz-Jaśkowiak A, Serafin Z, Szurowska E, Walecki JM. Management of patients with COVID-19 in radiology departments, and indications regarding imaging studies - recommendations of the Polish Medical Society of Radiology. Pol J Radiol 2020; 85: e209-e214.

17. Flisiak R, Horban A, Jaroszewicz J, Kozielewicz D, Pawłowska M, Parczewski M, Piekarska A, Simon K, Tomasiewicz K, Zarębska-Michaluk D. Management of SARSCoV-2 infection: recommendations of the Polish Association of Epidemiologists and Infectiologists. Annex no. 1 as of June 8, 2020. Pol Arch Intern Med 2020; 130: 557558.

18. Costa A, Weinstein ES, Sahoo DR, Thompson SC, Faccincani R, Ragazzoni L. How to build the plane while flying: VTE/PE thromboprophylaxis clinical guidelines for COVID-19 patients. Disaster Med Public Health Prep 2020. doi: 10.1017/dmp.2020.195.

\section{Address for correspondence:}

Dorota Zarębska-Michaluk MD, PhD

Department of Infectious Disease

Jan Kochanowski University

Provincial Hospital

Kielce, Poland

E-mail: dorota1010@tlen.pl 